\title{
Mapping and problematizing the enunciating subject within my documentary practice
}

\begin{abstract}
ABC Colombia, (86min, 2007) and Home Sweet Home, (90min. 2012) are the first two films of a trilogy exploring places and communities to which I am personally connected, questioning - from an insider/outsider perspective - the relationship between place and identity and notions of home and belonging. Through the analysis of both the process of making and the works' final form, the article examines the nature of documentary filmmaking as a relational process, a form of engagement with the world. Addressing how each film articulates questions of authorship, enunciation, narration and communication the article also traces and problematizes the surfacing of the enunciating subject, how I inhabit my films as an author. In particular, it critically engages with the shift from a more traditional 'participatory observation' mode of address to the progressive negotiation of a plurality of modes and 'voices', and to a more explicitly articulated personal viewpoint. In the ever-changing postmodern and post-grand narrative scene the challenge for a filmmaker today, I argue, is to develop a subjective cinema capable of negotiating the coexistence of different registers of address in open dialogue with each other, each interpellating the spectator in their own distinctive way.
\end{abstract}

Keywords: first-person documentary, subjective cinema, essay film, placeidentity; $A B C$ Colombia.

\section{Introduction}

Corporeal images are not just the images of other bodies; they are also images of the body behind the camera, and its relationship within the world.

D. MacDougall - The Corporeal Image

From the very beginning, documentary filmmaking has definitely and most significantly been for me a personal process of discovery and interrogation of reality, 
a form of engagement with the world that implicates subject, filmmaker and viewer alike. A practice-as-research conceived as a cognitive and relational process that is also a way of creating models of subjectivity, of articulating the experience of being in the world and the process of making sense of it, of fostering film's transformational power and social impact with an end-goal that exceeds and extends beyond the finished artefact. A process that - using the camera as a lens through which to explore and connect - favours experience over explanation, and which proceeds more by implication than by demonstration, often resulting in works that are difficult to reduce to the simple idea of 'a discourse about the world'.

In fact, if we agree that the heart of any documentary is, as Stella Bruzzi clearly points out, 'the very juncture between reality and the filmmaker' (Bruzzi, 2006:6), then I would argue that a film is more than the inevitable the result of a negotiation between reality and interpretation, reality and image. By bearing the traces of the encounter between the filmmaker and the subject, a film-text allows for the relational process through which the self engages with, gets to know and makes sense of the world, while making it at the same time visible, accessible to the viewer.

I would like to stress that what I am mostly concerned with addressing here is my filmmaking practice at its moment of inception, rather than at the level of its reception. As a filmmaker, I am uniquely situated to talk not so much about what my films mean to the collective spectator, but about how myself and the subjects of my films experience the act of making them; to reflect on the staging of the encounter between the self and the world as a self-reflexive narrative and on its authorial, 
subjective expression, rather than discussing the experience of spectatorship, or making assumption about audience reception. ${ }^{1}$

It should be acknowledged however that, being this not only a reflection on the process of making (a film, sense), but to some extent a retrospective evaluation of my own films as well, I am here therefore also acting as a spectator (in fact the 'only' spectator within this discourse). Hopefully this will result in an interesting synergy not only between the "then-filmmaker" and the "now-filmmaker-as-spectator-andauthor", but also between the notion of deep reflexivity and that of explanatory reflexivity (MacDougall, 1998), where the former inscribes the relationship through which the video was produced ${ }^{2}$, whereas the latter takes place after the event and it is more common in reflexive ethnographic writing. As Sarah Pink points out 'the processes of making sense are actually often collaborative in fieldwork and require a reflexive unraveling of the relationship and negotiations by which knowledge is produced in fieldwork, for which the work of "deep" (filmic) and "explanatory" (written) reflexivity that MacDougall identifies can be equally important' (2006:136).

My early work from the mid 1990s, and in particular Fine Pena Mai-Life After Life (1995), has been identified by Italian film critics and scholars ${ }^{3}$ as crucial to the renaissance of Italian documentary at the end of the ' 90 s, alongside that of a few

${ }^{1}$ In light of this, terms such as cognitive (from Latin cognoscere "to get to know, recognise") and relational should be best framed within a certain tradition of visual anthropology, which posits filmmaking as a way-of-knowing and making sense of the world, 'a new approach to anthropological knowledge' (MacDougall, 1998:61), rather than within the

${ }^{2}$ Allowing for the reflexive account of how the knowledge represented was produced to be embedded in the film narrative.

${ }^{3}$ Adriano Aprà and Marco Bertozzi (just to mention a few). 
other independent filmmakers such as Rossetto and Rosi. In A History of Italian Documentary: Images and Cultures of the Other Cinema, filmmaker and scholar Marco Bertozzi asserts,

[t]he importance of an aesthetic awareness - beyond the historic and sociological dimensions - becomes essential again. (...) The poetic treatment of reality operated by these authors ${ }^{4}$ invests both the formal and the metalinguistic aspects of this cinematographic practice. (...) The battle is for the irreducibility of thought into images, in favour of the autonomous ontology of the latter. It is here that the best documentary cinema becomes an art of reference for philosophical reflection, a discipline capable of creating its own formal concepts, well beyond narrative or content analysis. (Bertozzi, 2008: 258-59, translation my own)

More recently, however, my work has more deliberately taken on what Alisa Lebow defines as a 'first person' mode of address, 'films that speak from the articulated point of view of the filmmaker who readily acknowledges her subjective position.' (2012:1) In fact, it would be fair to say that one of the distinguishable trajectories within my body of work is that of the 'surfacing' of the authorial voice, with the traces of the 'body behind the camera' becoming increasingly visible, accessible constituents of the story being told. In this article I discuss some of the ways and modes this 'emergence' has manifested itself within my work and how self-inscription and subjectivity have been increasingly constructed and expressed through its concrete signifying practices.

I would like to highlight that both works discussed here engage with communities I inhabit, while remaining nonetheless a stranger. The fertile, albeit at times unsettling, condition of the stranger - in Georg Simmel's terms the potential

\footnotetext{
${ }^{4}$ Colusso, Rossetto, Rosi
} 
wanderer 'who comes today and stays tomorrow' - is by far the best way to define the particular place I look from, my insider/outsider perspective within these works.

\section{ABC Colombia}

As a filmmaker, I thus inhabit the world of the image, a world halfway between myself and reality. (Johan Van der Keuken, interview with Robert Daudelin in Cinémathèque Québécoise, Montreal, October 1974)

Along the Don Diego river, one of the many rivers that descend from the Colombia Sierra Nevada de Santa Marta, there is a small building of white cement, on whose walls the children have drawn the flora and fauna of the region. This is the schoolclass of the children of the local 'campesinos' (farmers). A single elementary class gathering 25 children between 5 and 15 years old, the age at which school ends around here. But not all children finish it. Many have already begun to work as 'raspachines' - coca leaf pickers - or to patrol the mountains for the paramilitary, to protect the area - where there are enormous stretches of coca plantation - from infiltration by guerrillas or the army.

$A B C$ Colombia is an intimate portrait of a small rural community in a part of Colombia entirely controlled by paramilitary forces, rendered through the eyes of the children who grow up there, and are often forced into very difficult choices. The documentary accompanies its young protagonists in this problematic setting through an entire school year, exploring some of the realities that nurture and perpetuate the violence in Colombia (Figure 1 ).

For me, Colombia is not a foreign country. Having decided to share my life with a Colombian, it has become one of the places of my existence, where I spend several months every year. The process of researching $A B C$ Colombia started in August 2004, alongside the construction of a home on a small piece of land in the 


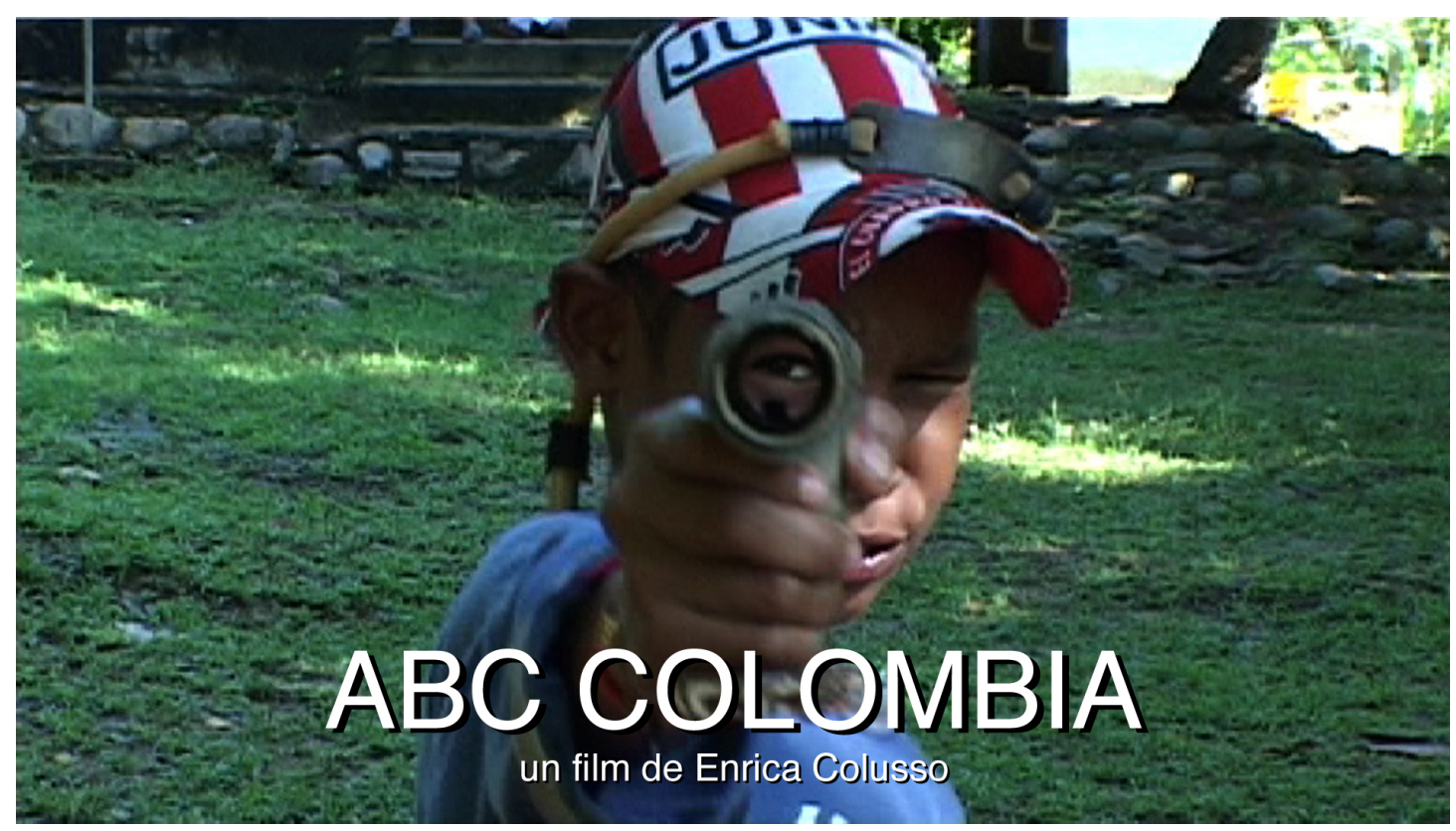

Figure 1. ABC Colombia, postcard.

Colombian Sierra Nevada of Santa Marta myself and my husband had bought, together with some friends, 10 years earlier.

$A B C$ Colombia represents the first work of a trilogy engaging with the significant places of my existence. In fact, one could go as far as saying that each film also constructs a possible site of inhabitancy, a proxy home. Having left my original home, Rome, more than half a century ago, this condition of displacement reinforces in me, I suppose, the generalised experience of the post-modern condition that Rascaroli identifies as one of the underling causes of the recent surge in first-person films. She writes:

Subjectivity in non-fiction forms of contemporary filmmaking is, I would argue, a reflection and a consequence of the increased fragmentation of the human experience in the postmodern, globalized world, and of our need and desire to find ways to represent such fragmentation, and to cope with it. (2009:5)

Nonetheless this underlying theme only became evident in its full implications much later in the process of making $A B C$ Colombia; possibly as late as during the various 
discussions following the screenings at festivals all over the word. As I was responding to the audience's questions about how such an intimate film was possible in such a difficult-to-access reality, the complexity of my belonging to this reality, my own particular relationship to this place and to these people hit home. After all, wasn't this a film about the children, rather than myself?

This late epiphany might sound odd, yet it is also quite useful in denoting the unconscious components at play in the act of filming, even for experienced selfreflexive filmmakers (or so I thought, as this was my $3^{\text {rd }}$ feature-length project, not to mention the many shorts...). It is increasingly evident to me, however, that the subconscious workings at play in the filmmaking process extend far beyond the actual shooting itself - the more obvious on-the-move responses to a situation that direct the camera choices on location. These seem to extend - unsurprisingly really - to the entire process: from the deep-rooted motivations that prod a filmmaker to engage with certain realities, to the strategies mobilised during the different phases of the process, to the kind of insights the process as well as the finished work unearth and deliver.

Moreover, this resistance to accept/admit - even to myself - that I could be, at least partially, the subject of my documentary work is, retrospectively, quite significant, as it could help to explain the tension between a practice that from the very beginning has had an existential dimension and is experienced as a personal commitment, and a form somewhat shy of fully embracing the rhetorical strategies of the essayistic, self-reflexive film. This latter approach has been described by Rascaroli as metalinguistic, autobiographical and reflexive, positing a well-defined, extra-textual authorial figure as its point of origin and constant reference (2009:3). This tension is indeed quite meaningful, as it also attests to two major forces at play in the context in which a filmmaker produces her work: on the one hand what is 
acceptable and encouraged by the production/distribution as well as the critical apparatus of filmmaking, and on the other what a filmmaker feels to be the best strategy to 'gain access to the real' in the ever shifting postmodern and post-grand narrative scene; an experience of reality the filmmaker shares with both subject and audience.

Re-examining $A B C$ Colombia's research and creative process, as well as the finished film, from today's perspective (a decade and a few works on) gives me that distanced vantage point from which to reconsider and interpret some of these questions (and choices made at the time). Retrospectively, this apparent, at least partial, disavowal of how personal all this was is particularity striking, given that $A B C$ Colombia's initial concept was clearly born out of a personal moral dilemma, an interior conflict that urged resolution: some of these children that I had seen grow up, and over the years transform into hardened adolescents, provoked complex feelings within me. What secrets were hidden in their elusive gaze? Could I still embrace them? Should I be afraid? Could I be at ease thinking myself as part of - albeit in my own particular way - this contentious community? How shall I respond to certain choices, which I found extremely difficult to come to terms with?

$A B C$ Colombia is, without doubt, principally an exploration of what it means to grow up in an area of conflict and to be confronted with very difficult choices. The extensive exposure and success of this award-winning film with a variety of audiences ${ }^{5}$ has contributed in its own way to shaping public discourse and enhancing

${ }^{5}$ ABC Colombia - which won several awards including the Spirit award at Brooklyn film festival - was screened at over 30 festivals and broadcast by ARTE, More4, PBS World 'Global Voices' and Yle Tv. It was also used by several organisations engaging in conflict analysis and resolution, including the USA Congress, while examining 
understanding of issues surrounding this disenfranchised and marginalised community. In a sense, therefore, I am not entirely surprised that - as $A B C$ Colombia's research and filming proceeded - the question of what would be the best strategies to tell the story from the children's perspective took over, overshadowing the more personal motivations that had initiated the process in the first place: my need to understand and come to terms with this reality, my necessity to situate myself within it. However, while this initial personal and emotional trigger had slightly retreated to the 'back of the mind', it was clearly still a powerful motivation working at the 'imaginative' level. The process of making the film thus also became my own way of engaging with this personal dilemma. And the frames, the shots, the scenes, turned into the arena where my own interior conflicts and resolutions interacted with the various conflicts and resolutions I was witnessing and mediating through the film; the sites where I dialogically situated myself in relationship to what I was witnessing. Now the question is: should this process have been more explicitly articulated and made part of the narrative?

In his introduction to The Subject of Documentary, Renov argues that the 'repression of subjectivity has been a persistent, ideologically driven fact of documentary history' (2004:xviii), however with direct cinema it became 'a cardinal virtue,' as clearly exemplified by Robert Drew's assertion that 'The filmmaker's personality is in no way directly involved in directing the action' ${ }^{6}$ Rejecting the pretence of invisibility, Rouch had, to be fair, always stressed the necessity of acknowledging the impact of the filmmaker's presence (as well as of involving the

Colombian paramilitary communities to inform votes on an aid bill, and screened at the Geneva Forum on Social Change (Geneva University, June 2009).

${ }^{6}$ Quoted in Renov, 2004:xxi 
persons filmed in the filmmaking process) and preferred to 'generate reality' rather than passively observe it, pushing participant observation to a new level of interactivity while also rehabilitating the use of voice-over as a narrative device by severing its association with the authoritarian tone of the expository mode. Nonetheless at the end of the 1980s, Les Ateliers VARAN in Paris and later even more so the British N.F.T.S ${ }^{7}$ were still permeated by the 'observational dogmas', which were rather hostile to the emergence of the subjective voice. It is quite possible then that this 'hostility' and consequent sense of guilt were still playing in the back of my mind as I navigated my way to a more assertive surfacing of the subjective voice, to establish myself as the 'well-defined, extra-textual authorial figure'. $A B C$ Colombia is, in fact, my first film with a clear autobiographical component, where my persona becomes more than 'a presence inscribed in the frame'; it becomes, albeit lightly, one of the characters. It is also the first film where my voice - speaking in the first person - is used as a narrative device, a way of locating myself in relationship to characters and situations. To speak the 'I' - Rascaroli argues - is 'firstly a political act of self-awareness and self-affirmation' (2009:2). However, while ABC Colombia is undoubtedly a subjective (if not an autobiographical) film, in its finished version this act of self-affirmation is somewhat restrained compared to the original editing plan. What follows is a noteworthy anecdote, which might serve to elucidate the pressures that might have contributed to the muted aspect of this nonetheless emergent subjective voice.

${ }^{7}$ In 1988/89 I attended Rouch's documentary school, before joining the N.F.T.S. The time spent at VARAN was quite influential in laying the seeds for the development of my self-reflexive and interrogative practice combining personal stories with political mindfulness. 
During the shooting, my husband - a trained architect-turned-filmmaker, who collaborated on ABC Colombia as field-producer - was also overseeing the construction of our house. This process - which ran parallel to the making of $A B C$ Colombia - was also filmed, initially as a way of documenting the construction. It soon became clear, however, that the building of the house provided a telling metaphor of the process of 'homemaking' within the community, a process that inevitably confronted me with difficult dilemmas. During the editing, the imagery of the construction of the house was woven in the film as a parallel story, becoming the 'place I spoke from', where my voice could be heard. As the school year proceeded, the building blocks of both the story and the house were assembled and given shape, till the final scene/conversation with Miguel Angel, the young protagonist, which closes the film. This is set in the newly finished house, which is built on the land where he was actually born and spent the first years of his life. Miguel Angel - now the age his brothers Pedrito and Chepe were when I first met them, still-a-child-butnot-for-much-longer - reflects, sitting in my hammock, on the future and on growing up.

In the discussion following one of the last screenings we had with the film commissioning editor from ARTE France Thierry Garrel before delivering the film to the channel, he suddenly observed, 'don't you think you should take away the scaffolding now that the structure is complete? Everything it signified is by now inscribed in the film, you don't need it any longer.' I was puzzled: Thierry, who is well known for his support of authored documentaries, had always encouraged me to include that material... Nonetheless we tried; the images of home-building were replaced by sequence-shots of journeying downriver and my voice, slightly reworked, was placed over them instead. Thierry was right, the film did stand on his 
own, and - to a great extent - the quality and intimacy of the dialogue between myself and the young protagonists spoke by itself. The final conversations with both Huriday and Miguel Angel are extremely personal, calling directly into question the nature of our relationship, one that clearly far exceeds, on both sides, that of filmmaker/subject. Nonetheless, the effect of getting rid of the 'scaffolding' was to significantly transform the film's mode of address, considerably weakening my position as the film's point of origin and constant reference, with the question of 'how I situate myself' receding into the background, and the personal process of coming to terms with this reality remaining mostly un-enunciated.

If we accept Rascaroli's assertion that the essence of an essay film has to be searched in its deep structures, as well as in the modality of viewing that it produces, getting rid of the 'visible structure' that carried the metanarrative of the 'homemaking' within the community rendered this process implicit, foreclosing audience access to my intimate journal of two significant parallel and entwined processes: that of coming to term with the moral dilemma that had motivated (and framed) the film and that of home-making. The latter, a process that could also be seen as symbolic of the filmmaking itself, conceived as an active process of construction of both meaning and selfhood. The film as it stands is far more straightforward and 'orthodox' formally - ultimately privileging a fundamentally narrative, albeit clearly subjective, approach - than it would have been if I had kept the superstructure of my own 'homemaking' story as the film's frame of reference.

I must admit that I was initially quite troubled by Thierry’s suggestion, which felt rather repressive of my desire, as an author, to shift towards a more complex range of rhetorical structures, one that combined several registers of address: pure observation, participatory, and self-reflexive, negotiating non-fiction narrative and 
essayistic (explicitly subjective/autobiographical, addressing the spectator directly through voice-over) modes, with the performance of the self been played out at different levels. However, if I interrogate my reasons for finally agreeing to this, I find their roots, at least partially, in a personal ambivalence I still felt at the time towards shifting from a presence inscribed in the images to a self-enunciating author(itarian) figure, framing the subjects filmed through my own discourse. This ambivalence included concerns about overshadowing, with my textual presence, the young protagonists, taking time and attention away from them and their challenges; about the (perceived) 'arrogance' of imagining my personal story as equally important alongside the children's, as well as a resistance to 'narcissistic-self-revelation' and possibly even a die hard suspicion of voice-over. Moreover, at that point, I was already fighting two other crucial battles: to have the film subtitled rather than dubbed (something that was becoming increasingly common in ARTE) and having my own voice, with its heavy accent, reading the text (rather than a French speaker). So it also became a question of priorities.

While far less self-reflective than originally envisaged, $A B C$ Colombia reveals, nonetheless, the personal position of the author, which can be inferred by a number of means (including voice-over) through which I, as the enunciator, intervene in the material. Let's explore the first movement (around 10min.), from the beginning until we reach the film's main setting, the one-room school.

The title refers to the Book of $\mathrm{ABC}$, a clear allusion to the theme of schooling, central to the narrative. However it also suggests that this is only an introduction, an initiation, to the utter complexity of Colombian reality while, for those who know it, also invoking Abbas Kiarostami's ABC Africa (2001). 
An image of a spider weaving its web at dawn opens the film. This almost minute-long shot presents a visual metaphor of the filmmaking process's ambivalent nature: patiently weaving together a coherent network of patterns of significance, a web, which is ultimately also a trap, an alluring tool for capturing and consuming. The shot sets the film's slow pace while also suggesting some of the film's themes, such as home-making and the remoteness of the rural context the film is set within, both beautifully enticing and deadly ${ }^{8}$.

The film then introduces the two main characters, Miguel Angel and Huriday. The informal conversation with Miguel Angel making lunch in his rudimentary rural kitchen is a good example of participatory mode (Figure 2). It establishes our relationship's familiarity and intimacy, while also introducing myself as the dialogical other in the scene. The scene introduces some of the film's main themes - such as coca crops as the area's main economy (which the whole community partakes in),

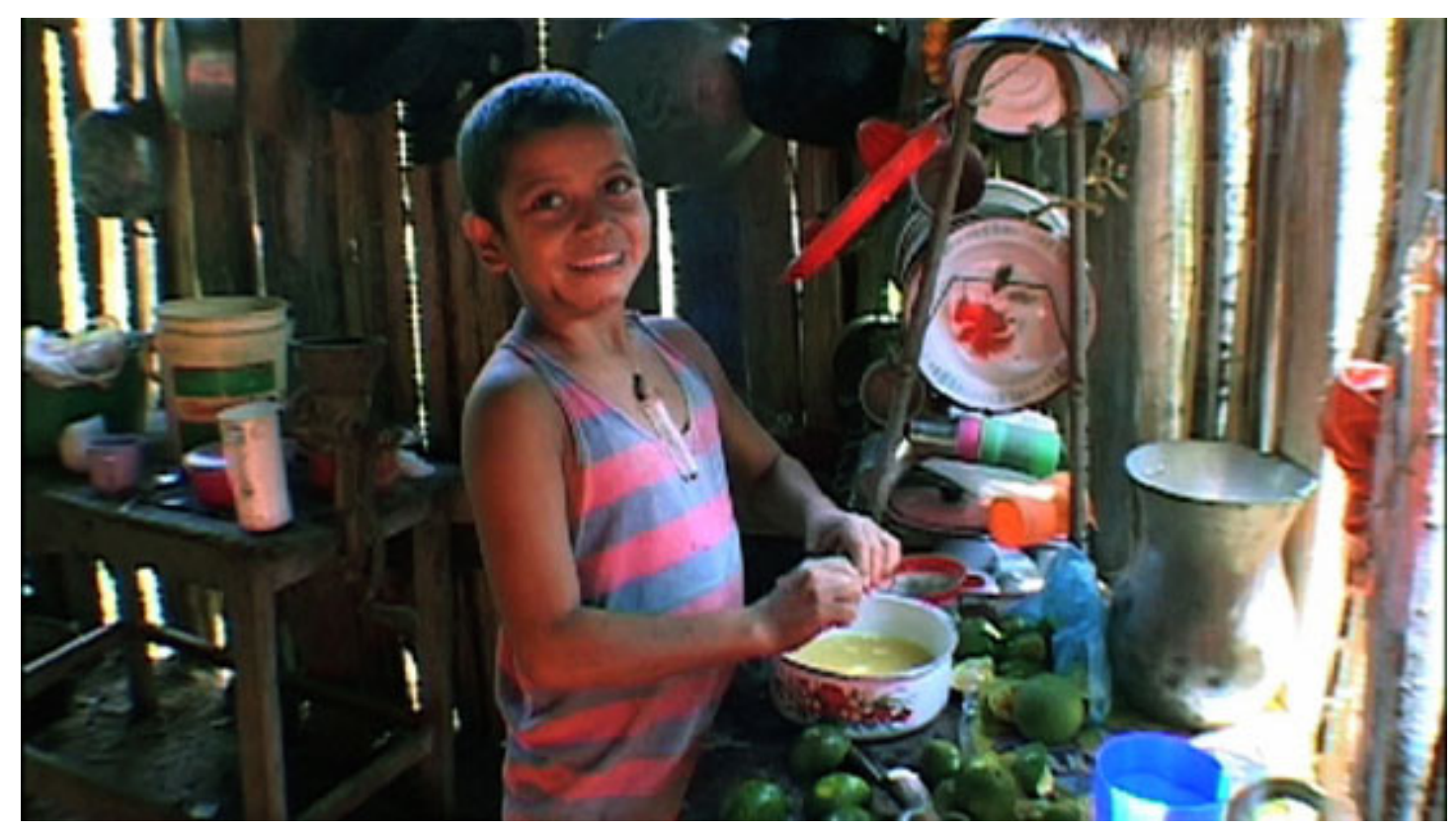

Figure 2. Miguel Angel in his kitchen (from the film).

\footnotetext{
${ }^{8}$ The theme of paradise versus hell is weaved throughout the film, generally through images of animals.
} 
with Miguel Angel owning his personal field and negotiating the crops with the buyers from an early age. We also learn that Miguel's brothers are fighting with the paramilitaries up in the mountains, and his apparent nonchalant attitude towards their potential death, 'if they die we will have to bury them, what else can we do...'

Huriday's introductory scene raises the theme of coca cropping to another level, away from the family context into the wider local economy controlled by the paras (who both grow and cook it, transforming it into cocaine), as the local youth's main source of employment. Over images of Huriday coca-picking (Figure 3), a coworker's voice intones the notorious 'corridos prohibidos', the 'forbidden ballads' chanting the gestures of the local mafiosos ${ }^{9}$. The corridos will be coming back throughout the film. A sort of counter-narrative presenting - in the form of codified and sung oral tradition - the local point-of-view, these glorifying self-portrayals of a sector of the local community embody the role models young boys look to emulate. Often played in their entirety over the images, listened to or sung by the young protagonists (including the children), the corridos - micro-stories within the story are one of the ways the huge out-of-frame reality and culture of violence the children are confronted with is brought into focus.

${ }^{9}$ Of Mexican origins, these corridos are forbidden as they glorify the narco/mafioso's culture and their values around violence, revenge, getting rich through illegal activities, defying the authorities, etc. Published illegally and distributed through the black market, the corridos are extremely popular with local youths, who feel a personal connection to the stories and know most of them by heart. 


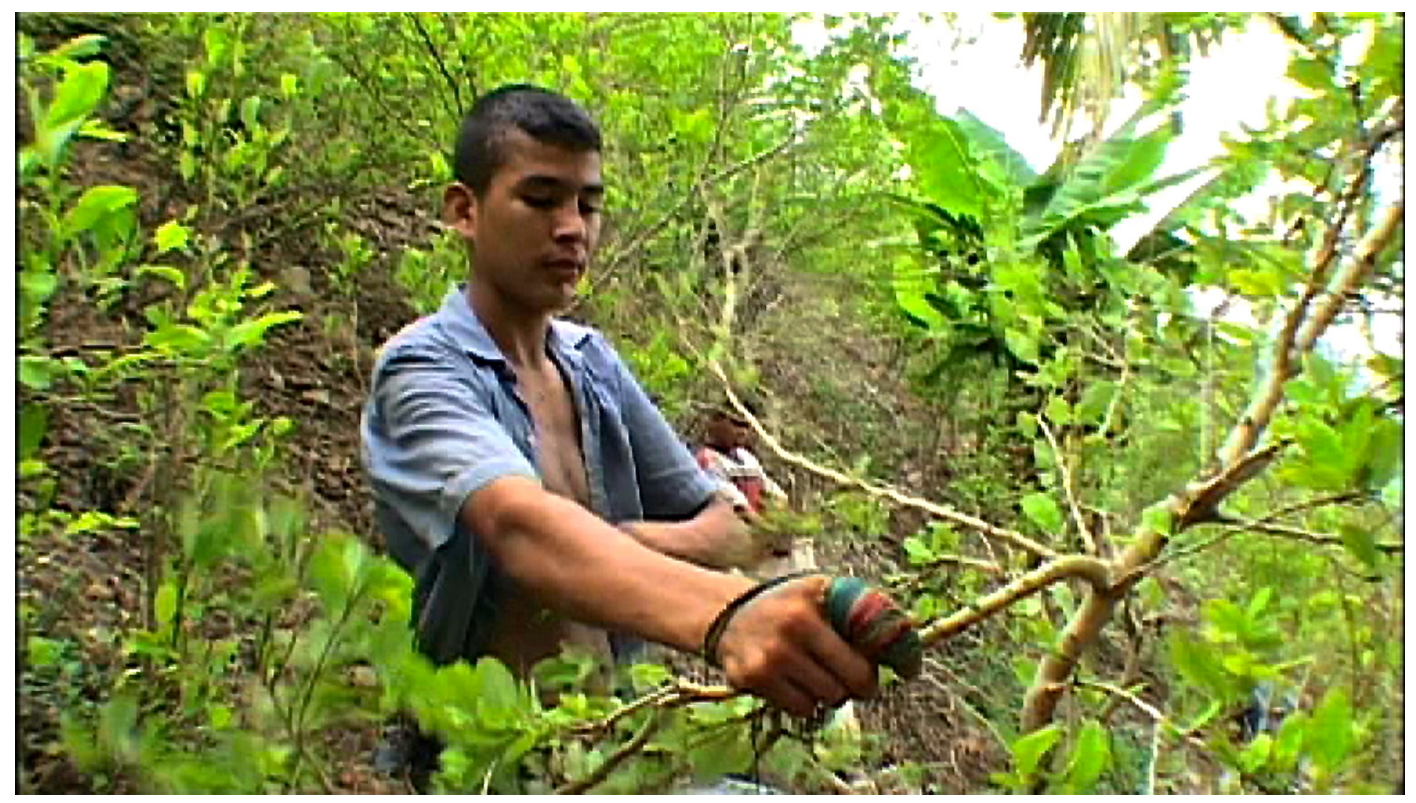

Figure 3. Huriday coca-picking (from the film).

Finally I present myself through my first voice-over, which leads to the introduction of the teacher, Lucenid, and of the film's main setting, the one-room school.

Miguel Angel and his family are the first people I got to know when I discovered the Sierra Nevada de Santa Marta, almost ten years ago.

Miguel Angel was only three at the time and his older brothers Pedrito and Chepe, must have been 12/13. Five years later they left to join the paramilitaries.

It was then that I met Huriday. He was 12, the same age as Miguel Angel is today.

The following year Huriday left home. When I asked news of him I was told he was going from field to field with a group of coca-pickers. They hardly saw him anymore.

Today Miguel Angel is still learning to read and write in the small school attended by the children of the local campesinos. Last year there was much 
coming and going of teachers and most of the children failed. This year a new teacher has arrived.

While factual in tone, this initial voice-over performs several functions; the first and most important is to explicitly address the nature of the enunciator's position in the film-text and locate it in relationship to people and place. The short narrative spans over 10 years - from when I first arrived to the Sierra till today - and is punctuated with several events that have happened in between, denoting a regularity of presence through time and familiarity with people and situations that set the extra-textual author in a particular position within this reality: someone who comes-and-goes, an outsider-insider, clearly not a filmmaker who visits with the sole purpose of making a film. Second, the text, by establishing significant parallels between the different ages of the children mentioned, poses one of the film's main questions and sets off what is at stake: will Miguel Angel eventually follow in his older brothers' footsteps?

Education is suggested as the only thing that might transform his destiny; a new teacher has arrived, will she make a difference? For Huriday, now the age Pedrito and Chepe were when they joined the paras, might it be too late?

\section{Home Sweet Home}

It is not in spite of embracing contingency, but precisely because of it, that documentary continues today, in this post grand-narratives era, to gain access to the real, albeit on a radically different basis.

Rascaroli - Personal Camera: Subjective Cinema and the Essay Film

The second work of the trilogy, Home Sweet Home explores yet another community I am personally connected to, that of the Elephant \& Castle, in London, where I have been living since 1997. Four years in the making, Home Sweet Home is a contemporary urban tale portraying the forces at play in the transformation of western 
metropolis and society. It tracks the people affected as well as the decision-makers behind the scenes of a massive urban regeneration, offering an intimate narrative of life and change in London. Set on an urban stage at the unfolding of one historical phase into another, the film engages with issues of crucial importance to today's society - such as social inclusion and urban sustainable development - here enacted in the process of 'city-making', and finally asks: what kind of society are we in the process of building? (Figure 4).

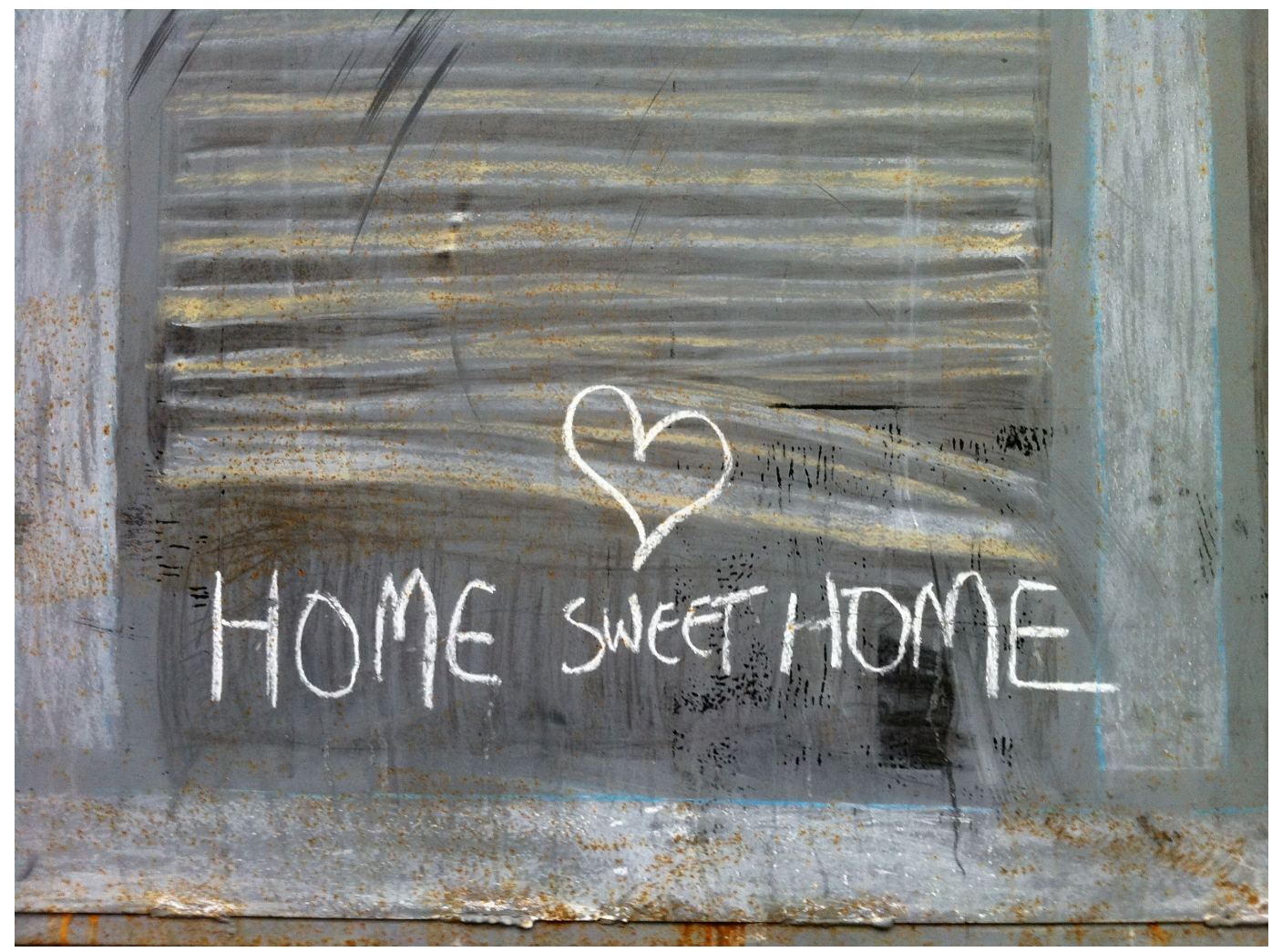

Figure 4. Home Sweet Home's title from the film; photo taken from a boarded-up home on the Heygate Estate, painted by their former residents.

While the move from a rural, 'third world' context to a global metropolis clearly marks a major difference and sets quite different challenges, both films share nonetheless similar working methods. These include extensive shooting and editing phases, a small crew, the identification of key settings (the one classroom school in ABC Colombia and the Heygate Estate in Home Sweet Home as well as key characters 
to accompany over time and, crucially, the importance of developing an intimate relationship with them, as they become, to a certain extent, participants and accomplices in the filmmaking process ${ }^{10}$. In the case of Home Sweet Home, this is particularly evident in my relationship to Helen, its main character. (Figure 5).

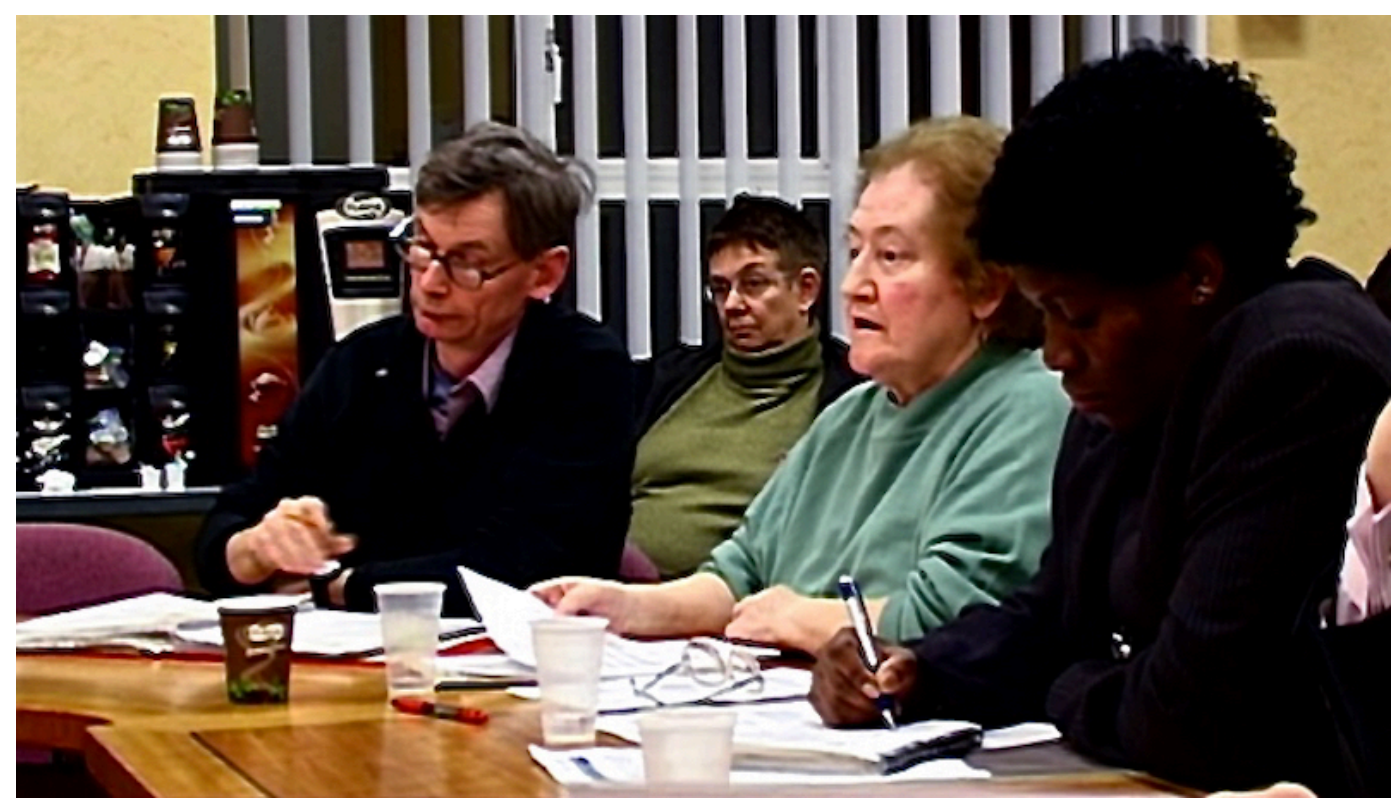

Figure 5. Helen at Southwark Overview and Scrutiny Committee (from the film).

It is in Home Sweet Home's formal strategies, however, that the challenges posed by the complexity of the urban experience - its underlying 'postmodernity' find their most obvious expression, pushing the observational/participatory approach to its limits and fragmenting the unity of time and space underpinning it. The result is a work considerably more self-reflexive and 'open' than $A B C$ Colombia, denoting a substantial shift in the authorial agency, now explicitly articulating a personal viewpoint, while negotiating the co-existence of a plurality of modes and 'voices', of

\footnotetext{
${ }^{10}$ For an extensive analysis of the relationship with my film characters and its ethical dimension see my article "The space between the filmmaker and the subject - the ethical encounter", Studies in Documentary Film Vol. 11, Iss. 2, 2017
} 
different registers of address, each interpellating ${ }^{11}$ the spectator in their own distinctive way (Rascaroli, 2009). This multivocality is particular relevant for a work aiming to interrogate the transformation of place in time from the experience of different participants. As Rodman points out in "Empowering Place: Multilocality and Multivocality." (1992), one-dimensional narratives disregard the multiplicity of forces that engender place. Arguing that multilocality allows for the expression of “polysemic meanings of place for different users" (1992:647), Rodman concludes that there "are often overlapping narratives of place" (1992:652). Naturally, these narratives may compete and contest one another, but such contestation further supports the multiple dimensions of place.

Conceived as a personal journey presented in the form of a visual diary, Home Sweet Home's structure weaves together the unfolding story of the transformation of the Elephant \& Castle and the various challenges its characters are confronted with via the filmmaker's perspective, which interacts and dialogues with the reality before it. Incorporating the participatory mode (and its narrative organisation) within a more complex, collage-like, multi-layered essayistic approach, the film multiplies the points-of-view, articulating a multi-perspective narrative - individual, often diverging, perspectives which counterpoint and play off each other - and breaks the unity of time and place characteristic of my previous works, also by introducing the historical dimension (both personal and collective) through the use of archives.

\footnotetext{
${ }^{11}$ Interpelling here is used from the author/filmmaker's perspective, speaking as a producer of narrative (rather than an interpreter), in this case one that is articulated as a multivocal and multimodal narrative, calling upon the spectator in different ways.
} 
The Heygate Estate is the principal setting of the film and the focal point of all the other perspectives, including that from my window (Figure 6), which looked directly onto the now-demolished estate. The narrative trajectory of the film accompanies the Heygate's gradual transformation from a living community into an empty carcass ready to be dismantled. My own status as the extra-textual authorial figure in Home Sweet Home is - like in ABC Colombia- that of the stranger, the insider/outsider 'who comes today and stays tomorrow'. However, differently from my previous film, this condition here is not only evidently and explicitly articulated from the very onset and throughout the film, but also literally stated through a direct quote of Simmel's concept in one of the voice-overs (@68min.)

Strangers amongst strangers, potential wanderers who come today and stay tomorrow, we yearn to belong.

But what does 'belong' exactly mean to those of us who inhabit a modern city?

And to whom does the city belong?

Referencing is actually a constant feature of Home Sweet Home, which uses a range of sources, from texts read from books ${ }^{12}$ (onscreen and offscreen) to visual references, such as the various 'screens in the screen', echoing Wenders' iconic visual meditation, Notebook on Cities and Cloths (1989).

Situatedness, where one looks from, the point of view, becomes indeed an explicit theme in the film, addressed in different ways both visually and textually. The 'view from my window' - overlapping the literal with the metaphorical - is its most

\footnotetext{
${ }^{12}$ The two books directly cited (and read onscreen) are Berger's And Our Faces, My Hearth, as Brief as Photos (2005) and Anna Milton's Ground Control: Fear and happiness in the twenty-first-century city (2012)
} 


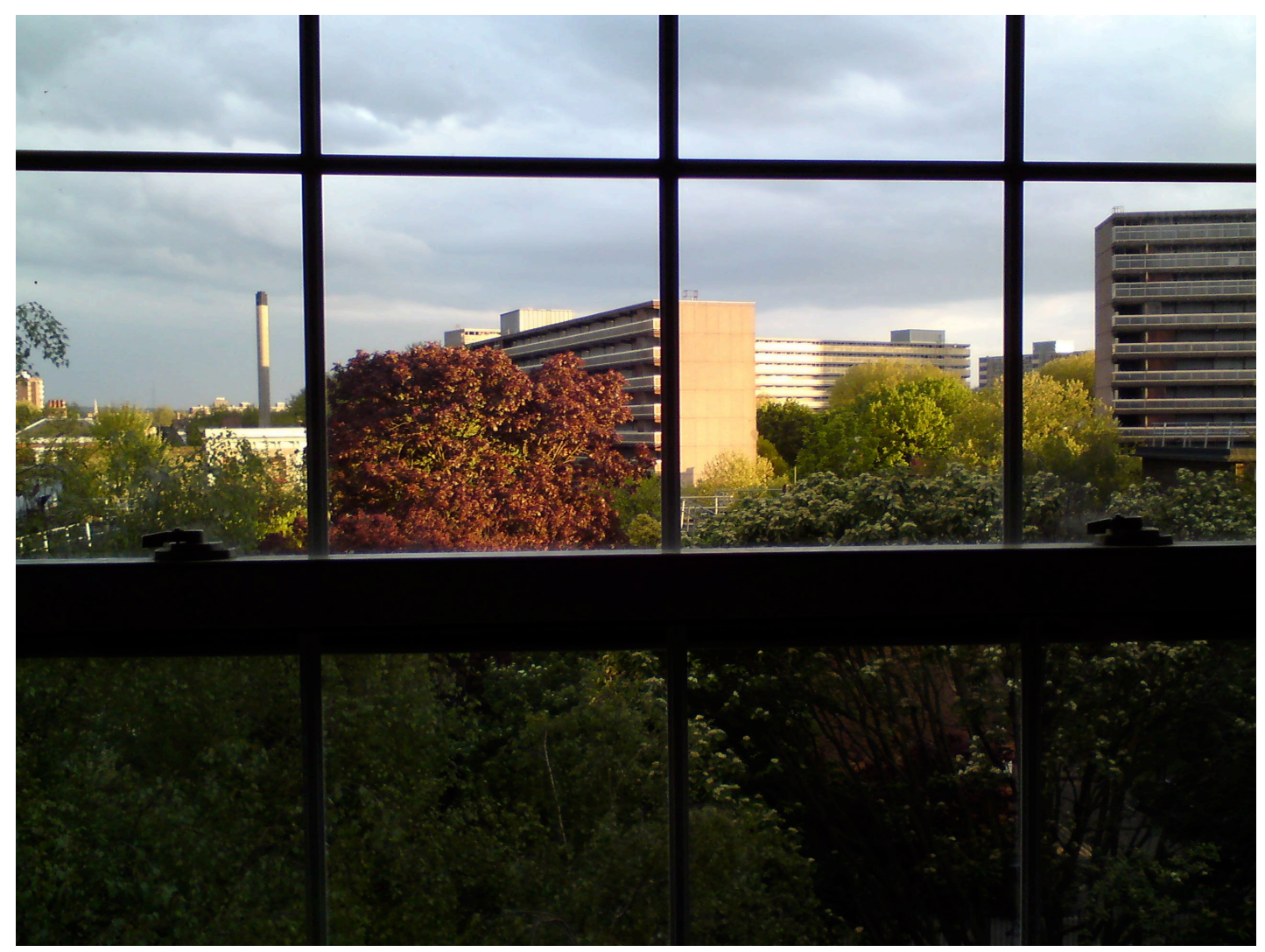

Figure 6. The Heygate Estate from my window.

explicit visual example (others being the various travelling shots, both within the Heygate and around the city, forming a visual analogue of my voice's searching and questioning $)^{13}$. A trope to which we come back season after season as the years go by and the story unfolds, $m y$ window frames the emptying estate, punctuating the passage of time while also establishing a visual link between my home and the film characters' homes.

The existential and significant relation between my own self, my environment and the city - as well as the notions of sense of place, belonging, familiarity (and

${ }^{13}$ These travelling shots invoke the figure of the flâneur (Benjamin). Also, as a way of 'walking through place', they can be seen as drawing parallels between walking in the city and ethnographic fieldwork, inviting viewer to attend to the "embodied and phenomenological aspects of place-making'. (Pink, 2008) 
consequent disruption provoked by displacement) - is addressed in an earlier text (@ 5.30min), which also explicitly sets the idea of the film diary:

Since May 2008 I have been keeping a film diary.

$(\ldots)$

Since I moved to the borough in 1997, the Heygate Estate has become such a familiar presence outside my window that it barely registers anymore.

Once this Brutalist citadel and its inhabitants have gone, my personal landscape, as well as part of London's core, will no longer be the same.

Will I miss it? And if so, what exactly will I grieve for?

The importance of place for creating and sustaining a sense of self is an idea captured in the environmental psychological concept of place-identity. As Dixon and Durrheim point out “Questions of 'who we are' are often intimately related to questions of 'where we are'." (2000:39) The notion suggests that environments do not simply serve as settings for individuals' activities, actions or behaviours but are instead actively 'incorporated' as part of the self. As a local resident and a filmmaker particularly interested in the relationship between people and the place they inhabit, their intrinsic involvement with one another, charting the regeneration of the Elephant \& Castle became a captivating and challenging journey of discovery and questioning of the city I have chosen, over 25 years ago, as my home. A journey allowing me to bear witness to the ebb and flow of its development and its fast-fading histories, to decipher and measure change, to question the politics and practices of place-making and the increasing privatisation of the city. The making of Home Sweet Home turned out to be, however, also a process of interrogating and constructing my own belonging to a community I had been part of for over 10 years but - a stranger among strangers - I knew little about. A process that while connecting me and unveiling the 
intimate fabric of the place (its anima loci) inevitably also became an interrogation of what it means to belong in a modern metropolis such as London.

Work on the discursive construction of place-identity examines how the narrative 'positioning of someone who is of a place can connect a speaker to the multiple established meanings and identities of that place' (Taylor, 2003:193). Similarly Sarbin (1983) has observed that place-identity requires the analysis of processes of 'emplotment' - the autobiographic rendering of self in terms of personal stories complete with plots, characters and, of course, physical and metaphoric settings. Storytelling as a form of dwelling (the shaping of chaos into meaningful forms sheltering from 'unreality') is beautifully addressed by Berger's poetical meditation And Our Faces, My Hearth, as Brief as Photos, where he evocatively describes home as 'no longer a dwelling but the untold story of a life being lived'.

Over the first travelling shots along the Heygate's notorious streets-in-the-sky - a movement that brings the spectator from the Heygate's outside into the estate's inner core, where we meet its first inhabitant, Ivy, and enter her home - my voice explicitly addresses filmmaking as a process of transformation of my relationship with the place, of actively constructing belonging. The insider/outsider perspective, as well as how 'where we look from' defines 'what we see' are also addressed:

Even though with the years the Heygate had become a familiar presence outside my window, I had never actually entered inside. The long blocks that surround it don't exactly invite you in. Like the walls of a fortified citadel, they guard its interior quarters from intruders.

Now that I walk its extensive grounds daily, and I have accessed some of its most intimate private corners, I have realised that you have a completely different feel for it depending if you're an insider or an outsider, and I have grown quite fond of this outdated, decaying structure. Of the sharp contrast between its harsh exteriors and the homely richness of some of its interiors. 
My characters' homes.

Situatedness, the place one looks from, home (the original village) and the global village are themes conjured right from the very start, the pre-title sequence. This is a 5min. montage piece cutting together found footage of the London riots posted and shared on the internet. The narrator's voice - even before her hands holding the screen appear later in the scene - establishes these images as the subjective point-ofview of the enunciator, who is looking at them streaming on her phone from another country; her country of origin.

August 2011

London is burning. People post dramatic images on You Tube.

I look at them on my phone from my family home in Italy.

For a moment, as the police charge, these images of authority surrounded by flames trying to re-impose order merge - in my mind - with those we have become so used to witnessing from Greece or the Middle East. As if London contained all possible worlds, streaming out through the countless screens of the virtual mega-city.

The second paragraph both reinforces subjectivity - 'in my mind' - and introduces a key concept, that of the virtual megacity, which coexists within the traditional city and complicates it, inevitably also complicating notions of belonging. At the antipodes of home - "the centre of the world, the place from which the world could be founded' (Berger, 2005) - the virtual megacity has neither centre nor periphery. It is in Marc Augé's (1995) terms - a 'non-place' ${ }^{14}$. The final section of the pre-title

\footnotetext{
${ }^{14}$ Augé distinguishes place as a physical space defined as 'relational, historical and concerned with identity' (1995:77), from non-places - spaces of transition absent of
} 
sequence is played over a black screen, as the 'virtual city' disconnects when 'my phone runs out of battery', and I am left to experience the here and now, and its incommensurability.

Lying on my back on the top of the hill I climbed to get a signal, I look up and see a falling star.

Time is back.

From the very beginning, Home Sweet Home problematizes the experience of both space and time, with the city becoming, once again, the ideal subject/stage where the paradoxes and tensions of (super)modernity are at play. ${ }^{15}$ Similar to the experience of modernity, humanity is again confronted with the feeling of disorientation, dehumanisation and loss of connection to embodied experience (this time due to the overwhelming condition of the globalised info-society).

Confronted with the necessity and the desire to address the question of authorial agency in this wired and wireless age, and to elaborate new ways of telling to represent it, I found that the model of the 'open work', theorised by literary critic Umberto Eco in the 1960s - works that, like epistemological metaphors, suggest "through the structure of the work, a structure of the world" (Eco, 2004:5) - still provides a relevant framework through which to critically reflect on and engage with the complexity of depicting the urban experience in a contemporary metropolis and its increasingly mediated nature. By combining a multiplicity of perspectives and

identity, human relationships, or the traces of history - which increasingly dominate our existence, and suggests that our sense of place, as old as humanity, is coming to an end. For a further understanding of this fascinating, albeit historically connoted, notion see: Augé, Non-Places: An Introduction to the Anthropology of Supermodernity.

${ }^{15}$ The city as environment and subject of artistic inquiry is central to modernity's dialectic between eternal and transitory. 
temporalities Home Sweet Home - pushing at the borders of non-linearity - is an attempt in that direction, giving rise to a 'conversation' with the heterogeneity that constitutes the contemporary past of our city.

\section{Questions of authorship, enunciation, narration}

When I started to research Home Sweet Home at the end of 2007, certain things were immediately clear to me, while others - like to what extent the film would be selfreflexive and essayistic - only emerged 'on the road', as I confronted the vastness of the theme/s and of the material gathered over the years. The question quickly became how to creatively document the radical multiplicity of urban environment, preserving attention to the details of the personal experience while constructing a legible and coherent whole. The essayistic style - capable, according to Renov, of encompassing all the functions that documentary has displayed since its origin (2004:74-85) and in which the 'descriptive and reflexive modalities are coupled' and 'the representation of the historical real is consciously filtered through a flux of subjectivity' (2004:70) thus emerged as the most suitable way to tell this complex tale.

The Heygate was always intended as the film's main stage, the skené where the drama unfolds - in many ways a character in itself - with its transformation from a living community to an empty carcass as the main narrative trajectory. Memory, both individual and collective, also played, however, an important role. When the 'local' is surgically extracted from locality, it becomes necessary to retrace its hidden, faint narratives and to recover its memories embodied in the stories of the people who have inhabited it, to seek to capture the spirit-of-place before it succumbs to the expectations of a world-city on the make. To film the makeover of this lowly borough, between the memories of a sweet and sour past, was to register the 
destruction of something which existed there, that was not only cement, concrete, cheap paint and small flats, but a form of life, a frame of mind, the hinged collective memory of a fundamental part of the history of London. This historical dimension (also depicting British society's transformation since the previous local regeneration in the 60's), together with the multi-perspectival nature of the overall narrative structure, thus fragmented the unity of space and time, multiplying the places and times characters spoke from and about, as well as the range of material used and the formats they were recorded on. There is no space here to discuss in detail the different characters present in the film. However it might be useful to briefly outline the various perspectives the film articulates:

(1) The perspective from the inside: the Heygate tenants'

(2) The local government perspective

(3) The external perspective: the architects and urban designers.

(4) The financial perspective: the developers

(5) The historical perspectives. This includes several elements, from Heygate's original architect Tim Tinker, to various kinds of archives, delivering both personal and official narratives.

(6) The filmmaker perspective: the view from my window

My presence in the film is inscribed and performed at different levels through:

- My text/voice-over

- Characters addressing me directly

- My hands shown holding the iPhone where images are playing, over the map of London, writing a diary or reading a book. 
- Showing the process of reviewing the material - either my own footage or the archives, introducing the figure of the diarist/researcher.

- The pov travelling-shots through the city and around the estate

Home Sweet Home thus moves between two quite different scales: on the micro end, the personal, the autobiographical, the intimate relationship with characters and place, and on the macro, the historical, socio-political reflection, while also including a selfreflexive element depicting the filmmaking process. These different layers are expressed by different modes of address.

The unfolding drama of the Heygate community's poignant demise is shot, much like $A B C$ Colombia, using participatory observation through mostly handheld DVCam accompanying the characters over time. Again this involved a very small crew, in fact I was often on my own. Home Sweet Home approach, however, is considerably more participatory/interactive than $A B C$ Colombia (combining intimate moments of exchange with the main characters and more formal interviews with institutional figures), with the purely observational used mostly for the scenes representing collective moments, such as the local government's side of the story (Council and local community meetings).

The second most prominent mode of address is the voice-over, which is not only far more extensive than in $A B C$ Colombia, but quite different in tone, responding to and interrogating the reality before it while also addressing and questioning the spectator directly. According to film theorist Raymond Bellour (discussing Chris Marker's CDRom Immemory) the 'openness' of the essay resides in its dialogic structure: 'The only real exchange resides in the address, the way the person who speaks to us situates himself in what he says, with respect to what he shows' (Bellour 1997:11). While clearly the interactivity of the CDRom affords a different kind of 
openness, Home Sweet Home while working at the limits of what's possible in terms of 'openness' given its linearity, nonetheless markedly aspires to a type of open, dialogic text. ${ }^{16}$ There are several moments in the film where I directly respond to what I have just shown, or to a character's comment or action. The interaction of the subjective perspective and the reality before it, the contrast between the voice-over subjectivity and the predominant objectivity of the images, become a testing and questioning of both, and the structure of the film follows the movement of that dialogue, with the audience forced to "acknowledge a conversation with the filmmaker" (Rascaroli, 2009:30).

As an author, I inscribe myself in the Home Sweet Home by playing several roles: the source of the act of communication 'who literally inhabits the text' (Ibid:33), a character personally implicated in the unfolding story, a researcher/commentator/filmmaker who, rather than presenting a clear point of view, opens up problems and interrogates the spectator. Moreover, Home Sweet Home's structure is that of a constant interpellation, with each spectator 'called upon to engage in a dialogical relationship with the enunciator, hence to become active, intellectually and emotionally, and interact with the text. (Ibid:35)

\section{Conclusion}

'Reality' is a term ever more problematic, dynamically constructed in our interaction with others and the world we inhabit and permeated by the co-existence of a

\footnotetext{
${ }^{16}$ My desire to explore open textuality further led me to experiment with non-linear narrative in my interactive database documentary Ghost Town (2013-16). I will further explore the notion of 'open work' in relationship to my recent interactive work in an article discussing my interactive documentary Ghost Town, forthcoming.
} 
multiplicity and diversity of ways of understanding our shared humanity. Filmmaking more than ever needs to be a process of 'negotiation', capable of encompassing diversity and plurality while attending to the responsibility of interrogating the world and its values, of fostering a critical understanding of our society and the forces at play within it.

In this article I have suggested the surfacing of the subjective voice as one possible way of responding to this increasingly fluid sense of reality and belonging, and I looked at filmmaking as a process of dwelling, of constructing belonging, with the audiovisual works as problematized places of inhabitance the author constructs, inviting viewers to share the experience.

I have argued that the challenge for a filmmaker today is to develop a subjective cinema capable of negotiating the coexistence of different registers of address in open dialogue with each other, generating thought-provoking reflections defined by unorthodoxy and openness; to respond to the demise of the 'naïve' observer by embracing the inherently performative nature of the 'society of the spectacle' and 'staging' works that foreground and critically engage with the constructed nature of any representation.

\section{NOTE}

The films underlying this article were submitted to the RAE 2008 and the REF2014.

\section{REFERENCES}

Augé, M. 1995. Non-Places: An Introduction to the Anthropology of Supermodernity. New York: Verso.

Bellour, R. 1997. “The Book, Back and Forth.” In Qu'est-ce qu'une medeliene? A 
propos du CDRom Immemory de Chris Marker, edited by Laurent Roth and Raymond Bellour. Paris: Yves Gevaert Editeur/Centre Georges Pompidou.

Berger, J. 2005. And Our Faces, My Hearth, as Brief as Photos. London: Bloomsbury.

Bertozzi, M. 2008. Storia del documentario Italiano. Immagini e culture dell'altro cinema. Venezia: Ed Marsilio.

Bruzzi, S. 2006. New Documentary. London, NY: Routledge.

Dixon, J., and K. Durrheim. 2000. "Displacing Place-Identity: A Discursive Approach to Locating Self and Other.” British Journal of Social Psychology 39 (Pt 1): $27-44$.

Eco, U. 2004. Opera Aperta - Forma e indeterminazione delle poetiche contemporanee. Milano: The Open Work. Bompiani. First published in 1962.

Kiarostami, A. 2001. ABC Africa, produced by Kiarostami and Marin Karmitz.

Lebow, A. 2012. The Cinema of Me: The Self and Subjectivity in First Person Documentary. London: Wallflower Press.

MacDougall, D. 1998. Transcultural Cinema. Princeton, NJ: Princeton University Press.

MacDougall, D. 2006. The Corporeal Image: Film, Ethnography, and the Senses. Princeton, NJ: Princeton University Press.

Milton, A. 2012. Ground Control: Fear and Happiness in the Twenty-First-Century City. London: Penguin.

Nannicelli, T., and P. Taberham. 2014. Cognitive Media Theory. New York: Routledge.

Pink, S. 2006. The Future of Visual Anthropology: Engaging the Senses. London: Routledge.

Pink, S. 2008. "Mobilising Visual Ethnography: Making Routes, Making Place and Making Images.” Forum Qualitative Sozialforschung/Forum: Qualitative Social Research 9 (3), Art. 36. http://nbnresolving.de/urn:nbn:de:0114fqs0803362.

Rascaroli, L. 2009. The Personal Camera: Subjective Cinema and the Essay Film. New York: Columbia University Press.

Renov, M. 2004. The Subject of Documentary. Minneapolis, MN: University of Minnesota Press.

Rodman, M. C. 1992. "Empowering Place: Multilocality and Multivocality." American Anthropologist, New Series 94 (3): 640-656. 
Sarbin, T. R. 1983. "Place Identity as the Component of an addendum.” Journal of Environmental Psychology 3: 337-342.

Simmel, G. 1950. “The Stranger (1908).” In The Sociology of Georg Simmel, translated by Kurt Wolff, 402-408. New York: Free Press.

Taylor, S. 2003 “A Place for the Future? Residence and Continuity in Women's Narratives of their Lives.” Narrative Inquiry 13: 193-215. 